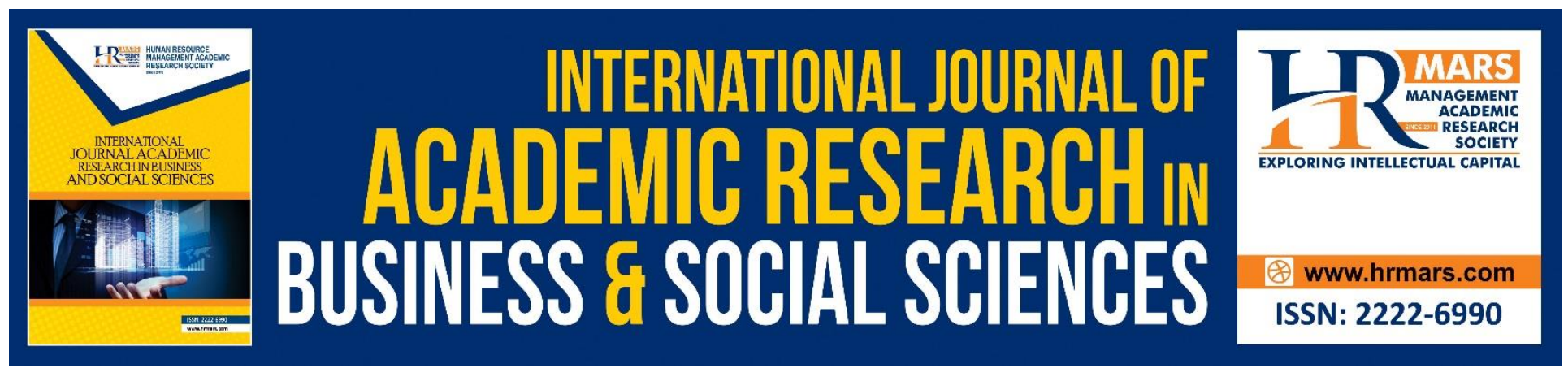

\title{
Corporate Governance Disclosure from Agency Theory Perspective: A Conceptual Model for Saudi Listed Companies
}

\author{
Maadi Bakor Omar, Azhar B Abdul Rahman
}

To Link this Article: http://dx.doi.org/10.6007/IJARBSS/v9-i5/5901

DOI: $10.6007 /$ IJARBSS/v9-i5/5901

Received: 22 March 2019, Revised: 01 April 2019, Accepted: 28 April 2019

Published Online: 29 May 2019

In-Text Citation: (Omar \& Rahman, 2019)

To Cite this Article: Omar, M. B., \& Rahman, A. B. A. (2019). Corporate Governance Disclosure from Agency Theory Perspective: A Conceptual Model for Saudi Listed Companies. International Journal of Academic Research Business and Social Sciences, 9(5), 518-530.

Copyright: (C) 2019 The Author(s)

Published by Human Resource Management Academic Research Society (www.hrmars.com)

This article is published under the Creative Commons Attribution (CC BY 4.0) license. Anyone may reproduce, distribute, translate and create derivative works of this article (for both commercial and non-commercial purposes), subject to full attribution to the original publication and authors. The full terms of this license may be seen at: http://creativecommons.org/licences/by/4.0/legalcode

Vol. 9, No. 5, 2019, Pg. 518 - 530

http://hrmars.com/index.php/pages/detail/IJARBSS

JOURNAL HOMEPAGE

Full Terms \& Conditions of access and use can be found at http://hrmars.com/index.php/pages/detail/publication-ethics 


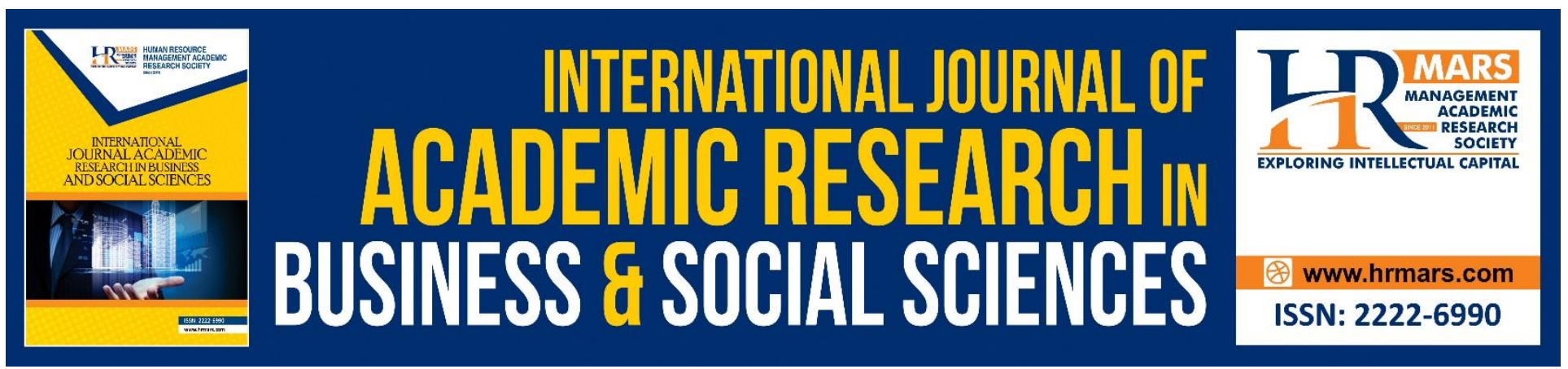

\title{
Corporate Governance Disclosure from Agency Theory Perspective: A Conceptual Model for Saudi Listed Companies
}

\author{
Maadi Bakor Omar, Azhar B Abdul Rahman \\ Tunku Puteri Intan Safinaz School of Accountancy, Universiti Utara Malaysia, \\ Email: azhar258@uum.edu.my,Email:maadi16130@hotmail.com, \\ Email: maadi16130@hotmail.com
}

\section{Abstract}

Objective: The study emanates from the phenomenal challenge of weak disclosure of corporate governance (CG) in the yearly reports of companies globally. Towards the goal of addressing this weak disclosure, this study develops a conceptual model aimed at better comprehension of factors influencing disclosure.

Methodology: This paper is developed on the basis of review of studies relating to CG board, from board directs aspect, specifically the agency theory perspective. The paper recognized three vital factors that possibly influence CG disclosure by Saudi listed companies. These factors are: board size, board independence, and board meeting.

Implication: The proposed model relating to agency perspective will be relevant to statutory bodies alongside organizations by identify factors that could influence disclosure in Saudi Arabia. Further empirical studies that will evolve from such framework will be a veritable tool towards the improvement of CG disclosure among the users of information relating to financial and non-financial statements for instance shareholders, creditors, investors.

Keywords: Saudi Arabia, Board Directors, Disclosures, Corporate Governance

\section{Introduction}

The role of corporate disclosure involves ensuring the availability of information on finance to stakeholders in corporations. Corporate disclosure is practiced by putting out fiscal information under either voluntary or compulsory condition through formal or non-formal means. Information release is controlled by sets of principles, which also governs company's transparency in terms of financial and non-financial matters (Gandia, 2008; Gibbins, Richardson \& Waterhouse, 1990). However, the principles of Corporate Governance (CG) are not precisely the same across countries in the world, because of the differences in economic and political background in individual country (Alzahrani, 2013). Because of the variations across countries, a general definition of CG is nearly 
INTERNATIONAL JOURNAL OF ACADEMIC RESEARCH IN BUSINESS AND SOCIAL SCIENCES Vol. 9, No. 5, May, 2019, E-ISSN: 2222-6990 @ 2019 HRMARS

unachievable. Corporate Governance is considered as "the system by which companies are directed and controlled" Alzahrani (2013). Nevertheless, this definition of CG is considered to be too generic, since its explanation does not specifically capture the scope of CG. Consequently, Mendez (2003) offered a specific description of CG as: "the framework of laws, rules, and procedures that regulate the interactions and relationships between the providers of capital (owners), the governing body (the board or boards in the two-tier system), senior managers and other parties that take part to varying degrees in the decision making process and are impacted by the company's dispositions and business activities. Corporate governance defines their respective roles and responsibilities and their influence in steering the course of the company". (p.243)

The application of CG cut across other domains or discipline such as; finance, economics, sociology and management. Several extant studies on CG lay focus on two specific theories, which are: first the agency theory and secondly stakeholder theory. While Agency theory pertains to finance and economics, Stakeholder theory is concerned with the social perspectives of CG (Alzahrani, 2013). The "Saudi Corporate Governance Regulations" (SCGRs) is targeted to upsurge all shareholder's protection level and also suggesting generic guiding principles for best practices that will be adopted by listed companies. While listed firms increased in number by year 2000, the size of market capitalization has showed little or no growth to reflect the value of the Saudi economy at both the domestic and global levels (Al-Filali \& Gallarotti, 2012). Consequent to this, reformations regarding CG and stock market system has been carried out in the country by means of academic research with stakeholders like financial specialists and investors as subject across countries (SFG, 2009; Alshehri \& Solomon, 2012). By early 2000s, Saudi government commenced reformation agenda on CG, along with plans to guide overall economic development (Al-Al-Matari, Al-Swidi, and Fadzil, 2012). The effect of the early reforms reflected in the appreciable growth in terms of market capitalization, increased number of firms, liquidity and visibility in its stock market (Alshehri \& Solomon, 2012). In 2006, the country official institutionalization of internal CG was carried out from the SCGC publication. During same year, the CG codes were implemented and made mandatory for every listed company to comply (Alzahrani, 2013). Nevertheless, ever since year 2003, the general governance restoration alongside CMA establishment was already in place (Al-Moataz \& Hussainey, 2012; Hussainey \& Al-Nodel, 2008; Soliman, 2013). The first accounting standards such as standard of disclosure and reporting transparency were all implemented as early as 1985 through the Commerce and Industry Ministry. This was then revised in 2002, to Certified Public Accountants (SOCPA). The reform as well covers projected to commit to full adoption of "the International Financial Reporting Standards" (IFRS) by the year 2017. Up till 2006, "The Companies Act of 1965" used to be the prime legislation employed Saudi to moderate behaviors of companies (Haniffa \& Hudaib, 2007; Husainey \& Al-Nodel, 2008). All these economic reformations had succeeded in driving economic growth in Saudi Arabia and positioned it among top stock market in the Middle East and rapidly growing economies in the world (Piesse, Strange, \& Toonsi, 2012). The current study proposes to develop a framework that covers the direct factors affecting CG disclosure in the context of Saudi Arabia. Specifically, the objective is to assess the influence of three board characteristics, mainly: board meeting, board independence and board size on CG disclosure based on the agency perspective. The following section presents the review of the literature for the development of the proposed framework. 
INTERNATIONAL JOURNAL OF ACADEMIC RESEARCH IN BUSINESS AND SOCIAL SCIENCES

Vol. 9, No. 5, May, 2019, E-ISSN: 2222-6990 @ 2019 HRMARS

\section{Literature Review and Hypothesis development}

This current section reviews the background on CG and regulatory legislation in Saudi Arabia. This achieved through analysis of previous studies on CG and the relationship between some CG characteristics (such as board's size, board's independence and board's meeting frequency) and CG disclosure by listed companies in Saudi.

\section{Board Size and Corporate Governance Disclosure}

The extant literature presented that a large board play a vital role in improving the internal governance mechanisms towards better effectiveness. Due to diversity in terms of their expertise, backgrounds, and abilities, which can assist the board to provide adequate and transparent disclosure of information (Pearce \& Zahra, 1992)? The boards a large is able to generate ideas in providing high levels of disclosure (Brown, Beekes, \& Verhoeven, 2011). From the perfective of agency theory, larger size of board of directors relates to higher rate of disclosure (Davidson, and Nemec, and Worrell, 1996). The size of board is a critical element in monitory of management behaviour (Allegrini \& Greco, 2013; Fama \& Jensen, 1983). Furthermore, Ntim and Soobaroyen (2013) established that managerial monitoring can bring about positive influence on disclosure. Larger firms are usually associated with highly complicated activities, thus having a high likelihood of larger number of directors in order to improve monitoring and control in the firms (Coles, Daniel, and Naveen, 2008). While in contrast, having large size of directors does not only result into communication deficit inform of reduced cooperation and interaction amongst directors (Beasley, 1996; Yermack, 1996), but it also affects the accountability of management and directors (Jensen, 1993; Lipton \& Lorsch, 1992). Likewise, Vafeas (1999) asserts that the influence of external parties posing as opportunists and exerting control over the CEOs of large boards. Owing to the fact that it is more problematic for management to control and overshadow larger boards, management reluctance to control becomes another issue associated with large boards (Muth \& Donaldson, 1998; Pfeifer, 1972, 1973; Provan, 1980; Zahra \& Pearce, 1989).

In terms of the ability of boards to operate efficiently, size can also impact it's overall capacity, with smaller boards commonly seen to be less efficient in terms of obtaining sources of funds, such as external funding (Alexander, Fennell \& Halpern, 1993; Goodstein, Gautam \& Boeker, 1994; Pfeifer, $1972,1973)$. Kiel and Nicholson further clarified that larger board improves the board's capacity to review departmental actions on disclosure of CG. A larger board enhances the overall operational efficiency of the board, as smaller boards appear to provide less disclosure as compared to larger ones (Alexander et al., 1993; Goodstein et al., 1994; Pfeifer, 1972, 1973). However, the protection of shareholders' interests is usually improved with large board size, as recognized by Dalton et al. (1999). The ability to review management's actions will also be increased with a larger board size (Kiel \& Nicholson, 2003).

Cicero et al. (2013) supports the point of view of American companies that alter their board size or board independence in consideration of changes in company-specific fundamentals. Cicero et al. assert that within the course of 12 years specifically 1991 to 2003, about 66\% of companies in United States had carried out change in board sizes. Furthermore, Cicero et al., found only $45 \%$ of the companies were able to achieve the targeted board size within a two-year time period. The change rate is considered to be positively associated with the benefits of ensuring adept boards. Alterations 
INTERNATIONAL JOURNAL OF ACADEMIC RESEARCH IN BUSINESS AND SOCIAL SCIENCES Vol. 9, No. 5, May, 2019, E-ISSN: 2222-6990 @ 2019 HRMARS

in board size were found to be related to the economic interest of having effectual board structures. As recommended by the committees, (Hampel Report, 1998, Malaysian code on corporate Governance, 2000, Revised 2007; Saudi code of corporate governance, 2006), companies may attain better flexibility of choice to select productive board and suitable size as the best practices of CG.

Therefore, the capability of the board to perform effective monitoring increases with the addition of more expert directors, all of whom can contribute in terms of being more effective in conducting their supervisory duties. Previous studies have explored the relationship between board size and disclosures (Byard, Lin \& Weintrop, 2006; Vafeas, 2000; Yermack, 1996). In the context of Saudi Arabian, the SCGC stipulates that the board of corporation should consist of a three-member and the minimum and eleven and the maximum. This has given the level of flexibility for the firms to maintain a board size that is suitable and productive. Given the divergent views concerning how board size relates to CG disclosure, extant literature is said to be unclear as evidences are improperly documented and remain scanty in literature. Although a number of substantial studies have reported positive findings between board size and disclosure (Akhtaruddin et al., 2009; Allegrini \& Greco, 2013; Meek et al., 1995; Ntim et al., 2012a; Samaha, K. Dahawy, K. Hussainey, K. and Stapleton, $\mathrm{P}, 2012)$. Hence, the following hypothesis is posited:

H1: There is a positive relationship between board size and the level of corporate governance disclosure.

\section{Board Independence and Corporate Governance Disclosure}

Generally, board independence is regarded as number of independent non-executive directors relative to the number of directors (Uadiale, 2010). The independent non-executive director assumes the responsibility of directing, for efficiency it is recommended that he should not have any relationship with the company (Clifford \& Evans, 1997). Barako, Hancock, and Izan, (2006); Haniffa and Cooke (2002) argued that independent directors posses added knowledge with experience, sufficiently enough to manage the board and committees, while simultaneously capable of monitoring the managers. This is due to fact that boards which are dominated by the independent directors are significantly and positively associated with level of disclosure (Donelly \& Mulcahy, 2008; Gisbert \& Navallas, 2013; Li et al., 2008; Yuen, Liu, Zhang and Lyu, 2009). Equally, there is a strong correlation between disclosure quality with non-executive directors, size of board, and Chief Executive Officer (CEO) duality (Al-Janadi, Rahman and Omar, 2013). Accordingly, board's independent directors are alleged to lessen occurrence of conflicts between "larger controlling shareholders and minority outside shareholders" (Anderson \& Reeb, 2004).

As discussed by other study such as Patelli and Prencipe (2007), the correlation between board independence and the information disclosed by companies is positive. Hence, the agency theory suggest that the independent boards encompass high capacity for limiting managerial opportunities (Allegrini \& Greco, 2013; Fama \& Jensen, 1983; Jensen \& Meckling, 1976), as well as protecting shareholders interest and reducing agency costs (Chalevas, 2011; Lipton \& Lorsch, 1992). Moreover, in accordance to the agency theory the company of independent directors has the control to reduce the parallel information in organizations (Allegrini \& Greco, 2013; La Porta, Lopdez-de-Silanes, Shleifer, and Vishney, 2002). Similarly, the study of Haniffa and Cooke (2002) employed 167 companies listed in "Malaysian in Kuala Lumpur Exchange" (KLSE). The finding of the study reveals 
INTERNATIONAL JOURNAL OF ACADEMIC RESEARCH IN BUSINESS AND SOCIAL SCIENCES Vol. 9, No. 5, May, 2019, E-ISSN: 2222-6990 @ 2019 HRMARS

that when independent directors are present, improvement in accountability and transparency are observed in the board. Meanwhile, in Hong Kong, board independence and CG disclosure by listed firms during the period of 2002 was explored by Chau and Gray (2010), their study found that the exploitations by firm executives is reduced by both board and the chairpersons independence.

Similarly in listed companies in Saudi, Ezzine (2011) and Mahadeo, Soobaroyen, and Hanuman (2012) found evidence that the issue of independent directors is still relatively new. While contrarily, Bozec (2005) opined that a high percentage of independent directors on the board might lead to excessive managerial monitoring, and this has the potential of reducing efficiency in managerial decisions. In the context of Saudi Arabia, in 2006 SCGC recommended that a larger section of the board directors should be non-executive. Accordingly the Saudi Code (2006) Part four, Article 12, Paragraphs (C) and (E) regarding board independence, Paragraph (C) states that "The majority of the members of the Board of Directors shall be non-executive members". Furthermore, Paragraph (E) also notes that "The independent members of the Board of Directors shall not be less than two members or one-third of the members, whichever is greater". Nonetheless, with regards to the issue of board and its independence, there is no specific balance. Similarly, the board's non-independent directors could constitute two-thirds of the members (Al-Abbas, 2008; Combined Code, 2003). The concept of an independent director have become more stringent and so also its criteria over time depending on the background and experience of every individual. Consequently, board independence have received a lot of scrutiny in empirical literature especially, concerning CG regulations (Chen, Sun, Ang, S. and $\mathrm{Wu}, 2011$; Johanson \& Ostergren, 2010). Thus, the second hypothesis is formulated as follows: H2: There is a positive relationship between board independence and corporate governance disclosure.

\section{Board Meetings and Corporate Governance Disclosure}

Board meetings refer to the aggregate of all meetings held by the board in a particular year. Literature have suggested a link between the increased board effectiveness and increase in the regularity of meeting (Vafeas, 1999). This result from the avenue it creates for enquiries and high rate of response obtained regarding the queries or enquiries. There is also the possibility that more participation result in lesser oversight of accounting issues, consequently ensuing high reporting quality (Firth, Fung, \& Rui, 2007). In terms of sufficiency in exchanging information amongst directors, it is perceived to be favourably influenced by higher frequency of board meetings (La-ksmana, 2008). La-ksmana (2008) further re affirm that regular meetings promote transparency and adequacy in information flow and also aids directors in monitoring trade mattes in the best interests of shareholders. Despite the fact that the Saudi Code (2006) has not yet detailed the specific number of meetings to be held by listed companies, it suggested 4 times yearly meeting so as to approve the financial statements on quarterly base (Alzahrani, 2014). It is expected that board size would increase the board activity by demanding for board meetings as supported by Vafeas (1999) and Brick and Chidambaran (2007). Vafeas (1999) found a significant relationship between board size and board meetings whereby an increased size of board would increase the demand for board meetings. In addition, Vafeas (1999) discovered a negative relationship between firms' disclosure and board meetings frequency on 307 US-listed firms between the year of 1990 to 1994. These findings were supported by previous study by Fich and Shivdasani (2006) who discovered that market showed fewer attention to the frequency of board 
meeting, by using the sample of 508 US-listed firms over the period of 1989-1995. Nonetheless, limited evidence was discovered in previous literature on board meetings and Vafeas (1999) examined the effect of board meetings on firm disclosure and found an opposite relationship between board meetings and firm value. Brick and Chidambaran (2007) reported that the characteristics of firm and governance activities are key determinants of board meetings. Furthermore, the impacts of board meetings on firm disclosure were clarified by Karamanou and Vafeas (2005) in the sense that such impacts might not only vary in terms of firm-level characteristics, but also in terms of country-specific CG, and legal and institutional policies. Moreover, Vafeas (1999) makes the suggestion that the frequency of board meetings is a proxy for the time required by directors in order to supervise management. He takes a sample of 307 companies listed in the USA for the period 1990-1994 and subsequently garners much empirical evidence to support the view that where boards meet more frequently following the occurrence of a crisis, it helps to improve achievements. On the other hand, Vefeas (1999) argued on limited time spend by directors is not normally used for the meaningful exchange of ideas amongst themselves. In fact, more mundane activities such as various formalities and the presentation of reports, take up a large portion of the meeting time, which decreases the time available for efficiently monitoring management (Lipton \& Lorsch, 1992). These activities have negative impact on the corporate disclosures. Importantly, board meetings are expensive in various ways, such as in terms of directors' meetings fees, managerial times, refreshments and travel expenses (Vafeas, 1999), all of which can have a negative impact on corporate achievement. In extant literature, there exists many arguments on the size of board considered to have significant effect on its efficiency and it could be measured by number of board meetings (see e.g. Vafeas, 1999). In Saudi Arabia, board meetings generally have great importance with respect to CG practices. Open discussions results in a full disclosure of the realities, hence reduction in the rate of negligence. For the case of the "Saudi Corporate Governance Act" (2006, it recommends that board ought to meet not less than four times every year and meetings have to be within four months interval (Alzahrani, 2014). Thus, increasing meeting frequency will develop management proficiency in terms of business operations, and consequently drive greater attention towards CG disclosure for both internal and external stakeholders. Hence it is hypothesized that:

H3: There is a positive relationship between the number of board meetings and the extent of corporate governance disclosure.

\section{Proposed Research Framework}

The proposed framework (as shown in Figure 1) is based on the agency theory, signifying that board size, board independence, and board meeting affect CG disclosure. Agency theory perception of an organization is that it represents variety of contracts between the principal (owner/shareholders) and agent (managers). The theory argues that agents are expected to act in the best interest of the principal. Agency theory suggests the management role to involve making sure that management resource fully maximizes owners' wealth. Berle and Means (1932) also ascertained that, in the absence of proper monitoring of management by the shareholders, it consequently result in agency problems, that is conflict of interests and separation of management and shareholders in the organization. According to Kren and Kerr (1993), to improve the relationship between principal and agent, agency cost should be adopted. It is widely renowned that the operation of improved CG 
INTERNATIONAL JOURNAL OF ACADEMIC RESEARCH IN BUSINESS AND SOCIAL SCIENCES Vol. 9, No. 5, May, 2019, E-ISSN: 2222-6990 @ 2019 HRMARS

practices is expected to enhance the overall observation of management, and further reduce issue in terms of data asymmetry. The most effective CG mechanisms are centred on the supervision of company management on behalf of investors and these board of directors (BOD) Markedly, through the (BOD) board, management will be guided to act on behalf of shareholders. Agency theory, considers board of directors as a function of control and argued that board play a significant role in mitigating the agency cost by applying required controls (Shleifer \& Vishny, 1997, p. 737).

\section{Figure 1: The Conceptual Framework of the Study}

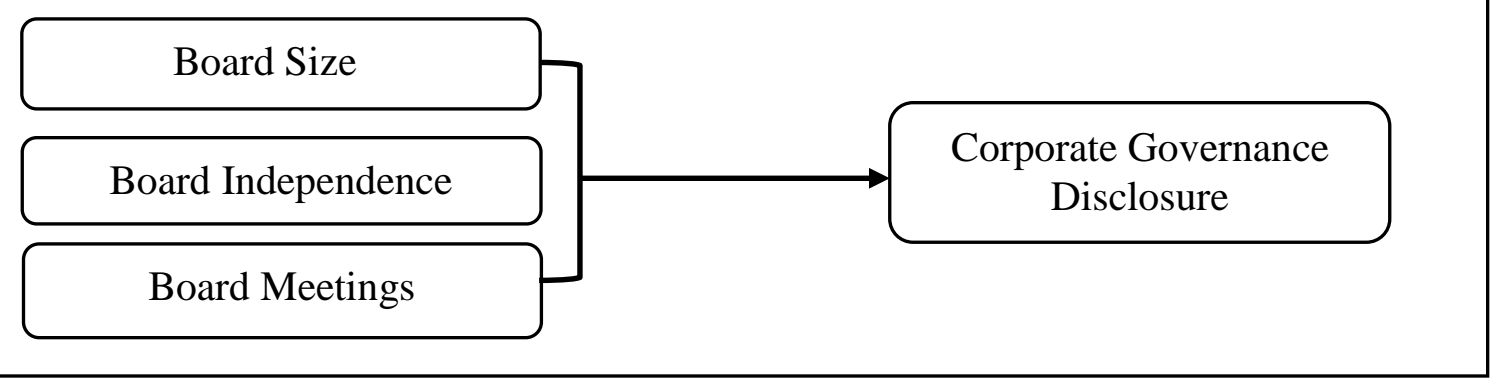

\section{Conclusion}

The paper reveals some elements of corporate governance, namely, on the structural association between corporate governance disclosures and board of directors' characteristics (size, independence, and meeting) with a focus on the Saudi Arabia companies. In Saudi Arabia context, economic environment and culture are not the same as those of the developed countries where most of the concepts and theoretical frameworks of corporate governance emanates from. Previous studies on corporate governance disclosure among the firms in Saudi Arabia have provided varied results compared to researches from developed countries. Generally, there are not many studies on the relationship between corporate governance disclosure and board characteristics in Saudi Arabia. Corporate governance involved human behaviour, business practices, and the different effect of multi- organizational environments and cultures. Hence there is the finding found a need for more empirical research on CG model for Saudi Arabia and other countries across the globe.

\section{Reference:}

Aktaruddin, M., Hossain, M. A., Hossain, M., \& Yao, L. (2009). Corporate governance and voluntary disclosure in corporate annual reports of Malaysian listed firms. The Journal of Applied Management Accounting Research, 7(1), 1-20.

Al-Abbas, M. A. (2008). Do Saudi companies underestimate us in the application of governance? Aleqtisadia Journal February 29, 2008, is available online at http://www.aleqt.com/2008/02/29/article11668.save.

Alexander, J. A., Fennell, M. L., \& Halpern, M. T. (1993). Leadership instability in hospitals: The influence of board-CEO relations and organizational growth and decline. Administrative Science Quarterly, 74-99.

Al-Filali, I. and Gallarotti, G. (2012). Smart Development: Saudi Arabia's Quest for a Knowledge Economy, International Studies, 49 (1-2), 47-76. 
INTERNATIONAL JOURNAL OF ACADEMIC RESEARCH IN BUSINESS AND SOCIAL SCIENCES Vol. 9, No. 5, May, 2019, E-ISSN: 2222-6990 ㄷ 2019 HRMARS

Al-Janadi, Y., Rahman, R. A. and Omar, N. H. (2013). Corporate Governance Mechanisms and Voluntary Disclosure in Saudi Arabia, Corporate Governance, Research Journal of Finance and Accounting, 4 (4), 25-35.

Alkhatib, A. A., Abdul-Jabbar, H., Marimuthu, M. (2018). The Effects of Deterrence Factors on Income Tax Evasion among Palestinian SMEs. International Journal of Academic Research in Accounting, Finance and Management Sciences 8 (4): 144-152.

Allegrini, M. and Greco, G. (2013). 'Corporate Boards, Audit Committees and Voluntary Disclosure: Evidence from Italian Listed Companies', Journal of Management and Governance, 17 (1), 187-216.

Allegrini, M. and Greco, G. (2013). Corporate Boards, Audit Committees and Voluntary Disclosure: Evidence from Italian Listed Companies. Journal of Management and Governance, 17 (1), 187 216.

Allegrini, M. and Greco, G. (2013). Corporate Boards, Audit Committees and Voluntary Disclosure: Evidence from Italian Listed Companies. Journal of Management and Governance, 17 (1), 187216.

Al-Matari, E. M. A. (2014). Non-Financial Public Listed Firms In Oman Ebrahim Mohammed Ayedh AlMatari Universiti Utara Malaysia September 2014. Phd Proposal. Universiti Utara Malaysia.

Al-Matari, E. M., Al-Swidi, A. K., Faudziah, H. B., \& Al-Matari, Y. A. (2012). The impact of board characteristics on firm performance: Evidence from Nonfinancial Listed Companies in Kuwaiti Stock Exchange. International Journal of Accounting and Financial Reporting, 2 (2), 310-332.

Al-Moataz, E., \& Hussainey, K. (2012). Determinants of corporate governance disclosure in Saudi companies. Journal of Economics and Management, 5 (1), 52-84.

Alsaeed, K. (2006). "The association between firm-specific characteristics and disclosure: the case of Saudi Arabia", Managerial Auditing Journal, 21 (5), 476-496.

Alshehri, A. and Solomon, J. (2012).The Evolution of Corporate Governance in Saudi Arabia, Conference Paper, British Accounting and Finance Association (BAFA), Brighton, UK.

Al-Thuneibat, A. A., Al-Rehaily, A. S. and Basodan, Y. A. (2015), "The impact of internal control requirements on profitability of Saudi shareholding companies", International Journal of Commerce and Management, 25 (2),196-217.

Al-Twaijry, A. A., Brierley, J. A. and Gwilliam, D. R. (2003), "The development of internal audit in Saudi Arabia: an institutional theory perspective", Critical Perspectives on Accounting, 14 (5), $507-$ 531.

Alzahrani, A. M. (2014). Corporate Governance And Firm Performance : A Study Of Public Listed Companies In The Kingdom Of Saudi Arabia Doctor Of Philosophy Universiti Utara Malaysia December 2014.Universiti Utara Malaysia, No. December.

Alzahrani, Y. A. (2013). "The corporate governance in Saudi Listed companies", International Journal of Humanities and Management Sciences, 1 (4), 243-254.

Alzahrani, Y. A. (2013). The corporate governance in Saudi Listed companies. International Journal of Humanities and Management Sciences, 1 (4), 243-254.

Anderson, R., \& Reeb, D. (2004). Board composition: Balancing family influence in S\&P 500 Firm. Administrative Science Quarterly, 4(9), 209-237. 
INTERNATIONAL JOURNAL OF ACADEMIC RESEARCH IN BUSINESS AND SOCIAL SCIENCES Vol. 9, No. 5, May, 2019, E-ISSN: 2222-6990 @ 2019 HRMARS

Barako, D., Hancock, P., and Izan, H., (2006). Factors influencing voluntary corporate disclosure by Kenyan companies, Corporate Governance.14 (2), 107-25.

Beasley, M. (1996). 'An Empirical Analysis of the Relationship between the Board of Director Composition and Financial Statement Fraud', The Accounting Review, 71 (4), 443-465.

Berle, A. and Means, G. (1932). The Modern Corporation and Private Property, Macmillan, New York, US.

Bozec, R. (2005). Boards of directors, market discipline and firm performance. Journal of Business Accounting, 32 (9\&10), 1921-1960.

Brick, I. E. and Chidambaran, N. K. (2007). "Board meetings, committee structure, and firm performance", unpublished manuscript, Rutgers University, New Jersey, NJ

Brown, P., Beekes, W., \& Verhoeven, P. (2011). Corporate governance, accounting and finance: A review. Accounting and finance, 51(1), 96-172.

Byard, D., Li, Y., \& Weintrop, J. (2006). Corporate governance and the quality of financial analysts' information. Journal of Accounting and Public Policy, 25(5), 609-625.

Cadbury, A. (1992). Report of the Committee on the Financial Aspects of Corporate Governance, Gee Publishing, London, 1-90.

Chalevas, C. (2011). 'The Effect of the Mandatory Adoption of Corporate Governance Mechanisms on Executive Compensation', the International Journal of Accounting, 46 (2), 138-174.

Chau, G., \& Gray, S. J. (2010). Family ownership, board independence and voluntary disclosure: Evidence from Hong Kong. Journal of International Accounting, Auditing and Taxation, 19 (2), 93-109.

Chen, S., Sun, Z., Tang, S. and Wu, D. (2011). Government Intervention and Investment Efficiency: Evidence from China. Journal of Corporate Finance, 17 (2), 259-271.

Cicero, D., Wintoki, M., \& Yang, T. (2010). Do Firms Adjust to a Target Board Structure? In CELS 2009 4th Annual Conference on Empirical Legal Studies Paper, is available onlineat http://corporategovernancecenter.org/Research/ CirMay11.pdf.

Clifford, P., \& Evans, R. (1997). Non-executive directors: A question of independence. Corporate Governance, $5(4), 224-231$.

Coles, J. Daniel, N. and Naveen, L. (2008). 'Boards: Does One Size Fit All', Journal of Financial Economics, 87, (2), 329-356.

Combined Code on Corporate Governance (2003), Combined Code on Corporate Governance, Financial Reporting Council, London.

Dalton, D. R., Daily, C. M., Ellstrand, A. E., \& Johnson, J. L. (1998). Meta-analytic reviews of board composition, leadership structure, and financial performance. Strategic management journal, 19(3), 269-290.

Davidson, W. and Nemec, C. and Worrell, D. (1996). 'The Influence of Board of Directors and Financial Performance on the Incidence of Executive Plurality', Corporate Governance: An International Review, 4 (1), 11-20.

Davidson, W. and Nemec, C. and Worrell, D. (1996). 'The Influence of Board of Directors and Financial Performance on the Incidence of Executive Plurality', Corporate Governance: An International Review, 4, (1), 11-20. 
INTERNATIONAL JOURNAL OF ACADEMIC RESEARCH IN BUSINESS AND SOCIAL SCIENCES

Vol. 9, No. 5, May, 2019, E-ISSN: 2222-6990 @ 2019 HRMARS

Donelly R. and Mulcahy, M. (2008), "Board Structure, Ownership and Voluntary Disclosure in Ireland", Corporate Governance: An International Review, 16 (5), 416-429.

Ezzine, H. (2012) A cross Saudi firm analysis of the impact of corporate governance on the stock price performance during the recent financial crisis. SABIC Chair for IFMS.

Fama, E. F. and Jensen, M. C. (1983). Separation of ownership and control. Journal of Law \& Economics, 26 (2), 301-325.

Fich, E. M. and Shivdasani, A. (2006). Are busy boards effective monitors?. Journal of Finance, (61), 689-724.

Gandia, J. (2008). Determinants of internet-based corporate governance disclosure by Spanish listed companies. Online Information Review Journal, 32 (6), 791-817.

Gibbins, M., Richardson, A., \& Waterhouse, J. (1990). The management of corporate financial disclosure: opportunism, ritualism, policies, and processes. Journal of Accounting Research, 28 (1), 121-143.

Gisbert, A. and Navallas, B. (2013). "The association between voluntary disclosure and corporate governance in the presence of severe agency conflicts", Advances in Accounting, 29 (2), 286 298.

Goodstein, J., Gautam, K., \& Boeker, W. (1994). The effects of board size and diversity on strategic change. Strategic management journal, 15(3), 241-250.

Hampel Report. London Stock Exchange (United Kingdom). (1998). Committee on Corporate Governance final report. London Stock Exchange (United Kingdom): Gee Publishing Ltd.

Haniffa, R. M. and Cooke, T. E. (2002). Culture, corporate governance and disclosure in Malaysian corporations. Abacus, 38 (3), 317-49.

Hussainey, K. and Al-Nodel, A. (2008), "Corporate governance online reporting by Saudi listed companies", in Tsamenyi, M. and Uddin, S. (Eds), Research in Accounting in Emerging Economies, Emerald Group Publishing, Bradford, (8),39-64.

Hussainey, K., \& Al-Nodel, A. (2008).Corporate governance online reporting by Saudi listed companies. Research in Accounting in Emerging Economies, (8), 39- 64.

Jensen, M. C. (1983). Organization and theory and methodology, The Accounting Review, 58, 319339.

Jensen, M. C. and Meckling, W. H. (1976). The theory of a firm: managerial behaviour, agency costs and ownership structure. Journal of Financial Economics, 3 (4), 305-360.

Johanson, D. and Ostergren, K. (2010). 'The Movement Toward Independent Directors on Boards: A Comparative Analysis of Sweden and the UK', Corporate Governance: An International Review, $18(6)$, 527-539.

Karamanou, I., \& Vafeas, N. (2005). The association between corporate boards, audit committees, and management earnings forecasts: An empirical analysis. Journal of Accounting research, 43(3), 453-486.

Kiel, G. C., \& Nicholson, G. J. (2003). Board composition and corporate performance: how the Australian experience informs contrasting theories of corporate governance. Corporate Governance: An International Review, 11(3), 189-205.

Kren, L., \& Kerr, J. L. (1993). The effect of behavior monitoring and uncertainty in the use of performance contingent compensation. Accounting and Business Research, 23(9), 159-168. 
INTERNATIONAL JOURNAL OF ACADEMIC RESEARCH IN BUSINESS AND SOCIAL SCIENCES

Vol. 9, No. 5, May, 2019, E-ISSN: 2222-6990 @ 2019 HRMARS

La Porta, R., Lopdez-de-Silanes, F., Shleifer, A. and Vishney, R. (2002). Investor protection and corporate valuation. Journal of Finance, 57 (3), 1147-1170.

La-ksmana, I. (2008), Corporate board governance and voluntary disclosure of executive compensation practices. Contemporary Accounting Research, 25 (4), 1147-1182.

Lipton, M., \& Lorsch, J. W. (1992). A modest proposal for improved corporate governance. The Business Lawyer, 48 (1), 59-77.

Mahadeo, J. Soobaroyen, T and Hanuman, V. (2012). Board Composition and Financial Performance: Uncovering the Effects of Diversity in an Emerging Economy, Journal of Business Ethics, 105 (3), 375-388.

Meek, G., Roberts, C., \& Gray, S. (1995). Factors influencing voluntary annual report disclosures by U.S., U.K. and continental European multinational corporations. Journal of International Business Studies, 26 (3), 555-572.

Mendez, M. (2003). Corporate governance; a US/EU comparison. University of Washington-Global Business Center.

Muth, M., \& Donaldson, L. (1998). Stewardship theory and board structure: a contingency approach. Corporate Governance: An International Review, 6 (1), 5-28.

Ntim, C. and Soobaroyen, T. (2013). Black Economic Empowerment Disclosures by South African Listed Corporations: The Influence of Ownership and Board Characteristics. Journal of Business Ethics, 116 (1), 121-138.

Ntim, C. Opong, K. Danbolt, J. and Thomas, D. (2012a). Voluntary Corporate Governance Disclosures by Post-Apartheid South African Corporations. Journal of Applied Accounting Research, 13 (2), 122-144.

Omar, M. B., Rahman, A. B. A, bin Abdul Hamid, F.Z. (2018). The Association between Corporate Governance and Disclosure of Audit committee Characteristics: A Conceptual Model for the Saudi Listed Companies, International Journal of Academic Research in Accounting, Finance and Management Sciences 8 (3): 321-333.

Patelli, L., \& Prencipe, A. (2007). The relationship between voluntary disclosure and independent directors in the presence of a dominant shareholder. European Accounting Review, 16 (1), 533.

Pearce, J. A., \& Zahra, S. A. (1992). Board composition from a strategic contingency perspective. Journal of management studies, 29(4), 411-438.

Pfeffer, J. (1972). Size and composition of corporate boards of directors: The organization and its environment. Administrative Science Quarterly, 18, 218-228.

Pfeffer, J. (1973). Size, composition, and function of hospital boards of directors: A study of organization-environment linkage. Administrative Science Quarterly, 17, 349-364.

Piesse, J., Strange, R., and Toonsi, F., (2012). Is there a Distinctive MENA Model of Corporate Governance? Journal of Management \& Governance, 16 (4) 645681.

Provan, K. G. (1980). Board power and organizational effectiveness among human service agencies. Academy of Management Journal, 23(2), 221-236.

Samaha, K. Dahawy, K. Hussainey, K. and Stapleton, P. (2012). The Extent of Corporate Governance Disclosure and its Determinants in a Developing Market: The Case of Egypt. Advances in Accounting, 28 (1), 168-178. 
INTERNATIONAL JOURNAL OF ACADEMIC RESEARCH IN BUSINESS AND SOCIAL SCIENCES

Vol. 9, No. 5, May, 2019, E-ISSN: 2222-6990 (C) 2019 HRMARS

SFG (2009). The Saudi Stock Market: Structural Issues, Recent Performance and Outlook, Samba Financial Group, Riyadh, Saudi Arabia.

Shleifer, A. and Vishny, R. W. (1997). A survey of corporate governance. The Journal of Finance, 52 (2), 737-783.

Uadiale, O. M. (2010). The impact of board structure on corporate financial performance in Nigeria. International Journal of Business and Management, 5 (10), 155-166.

Vafeas, N. (1999). Board meeting frequency and firm performance. Journal of Financial Economics, 53 (1), 113-142.

Vafeas, N. (2000). The determinants of compensation committee membership. Corporate Governance: An International Review, (8), 356-366.

World Bank (2009). "Corporate governance country assessment, Kingdom of Saudi Arabia”, Report on Observance of Standards and Codes (ROSC) Program.

Yermack, D. (1996). 'Higher Market Valuation of Companies with a Small Board of Directors', Journal of Financial Economics, 40 (2), 185-211.

Yuen, C. Y. D., Steven, Z. X., Morris, L. M., \& Lu, V. C. (2009). Case study of voluntary disclosure by Chinese enterprises. Asian Journal of Finance \& Accounting, 1 (2),

Zahra, S. A., \& Pearce, J. A. (1989). Board composition from a strategic contingency perspective. Journal of Management Studies, 29 (4), 411-438.

\section{Corresponding Author}

Maadi Bakor Omar

Email: maadi16130@hotmail.com 